\title{
Ecological differences between the isomorphic reproductive phases of two species of Iridaea (Rhodophyta: Gigartinales)
}

\author{
G. Hannach* \& B. Santelices \\ Departamento de Biología Ambiental y de Poblaciones, Facultad de Ciencias Biológicas, Pontificia Universidad Católica de \\ Chile, Casilla 114-D, Santiago, Chile**
}

\begin{abstract}
This study tests the hypothesis that species traditionally characterized as isomorphic exhibit similar physiological and ecological responses to different environmental factors, by comparing the ecological and ecophysiological responses of reproductive phases of 2 isomorphic species of Iridaea. Results indicate that although the tetrasporic and cystocarpic phases of $I$. Iaminarioides and I. ciliata have similar morphology, they do not have identical responses to ecological variables. In the field, the reproductive stages differ in their relative abundances and in their patterns of spatial and temporal distribution. In laboratory experiments, the reproductive phases showed intraspecific differences in growth rates under conditions of varying temperature, light intensity, water movement and salinity. Differences in susceptibility to grazing vary from juvenile to adult frond and from one grazer to another. The degree of ecological divergence between phases found was greater in the upper intertidal I. laminarioides and smaller in the low intertidal-shallow subtidal I. ciliata. Cystocarpic thalli of $I$. laminarioides dominated the upper margin of species distribution and grew faster than tetrasporic thalli under several laboratory conditions. In both species the cystocarpic phase was more abundant in the field than the tetrasporic phase. These results call into question the general belief of increased adaptivity of diploidy over haploidy in the algae.
\end{abstract}

\section{INTRODUCTION}

Isomorphic and heteromorphic life histories are equally well represented in all 3 Divisions of macroalgae (Chlorophyta, Rhodophyta, Phaeophyta; for review see Bold \& Wynne 1978). Particular patterns of heteromorphism can be recognized for most Orders of red and brown algae. These patterns frequently include the alternation of prostrate and upright morphs, as in most heteromorphic red algae; and of microscopic and macroscopic morphs, as in kelps. Stebbins \& Hill (1980) have postulated that heteromorphic alternation of generations derived from isomorphic alternation of generations. They claim that the adaptive value of alternation of generations lies partly in the adaptiveness of polyploidy itself, and partly in the adaptiveness of a haploid-diploid cycle in a seasonally fluctuating habitat, or in a place where 2 some-

\footnotetext{
- Present address: Department of Botany, University of Washington, Seattle, Washington 98195, USA

- Address for reprint requests
}

what dissimilar habitats exist side by side. According to Istock (1967), complex life cycles are evolutionarily unstable because, as selection acts independently on the reproductive stages, one of them will be reduced or lost in favor of the other. Thus, it seems likely that heteromorphic life cycles were derived from isomorphic life cycles by disruptive selection.

There is some evidence to support the idea that heteromorphism in algae is an adaptive response to stressful environments. It has been shown for a few species that different morphs have different responses to environmental factors (Nakamura \& Tatewaki 1975. Lubchenco \& Cubit 1980, Littler \& Littler 1983). Although our knowledge of the effect of abiotic factors on different morphs is still very limited, it has been suggested that upright morphs have a higher growth rate, are more productive and shorter lived than their alternate, non-upright morphs. However, this has been conclusively shown only for Gigartina papillata and Scytosiphon lomentaria (Littler \& Littler 1980, 1983). Resistance to grazing has been studied in some crustfrond alternating species (Lubchenco \& Cubit 1980, 
Slocum 1980, Dethier 1981), all of which suggest that heteromorphism might be an adaptive response to grazing.

These reports tend to support the hypothesis that heteromorphism is an adaptation to spatially or temporally variable environments. If the reproductive stages of isomorphic species occur in variable environments, they are expected to be under different selective pressures. If this is so one can question whether organisms that are traditionally characterized as isomorphic are strictly so, and whether their isomorphic phases can be considered to be ecologically equivalent. Are the 2 phases of isomorphic species really similar or are there some differences in respect to their morphology, physiology or ecology?

Only fragmentary information is available on differences between the reproductive phases of isomorphic species. Observations on differences in morphological traits include: a smaller gametophyte relative to the sporophyte (West 1968, Bold \& Wynne 1978, p. 300); differences in branching patterns (Garbary et al. 1980); basal filament system (West 1968); spore diameter in red algae (Nakamura 1954, Coon et al. 1972, Mshigeni 1976); and chemical differences in carrageenan composition of Gigartinaceae (Chen et al. 1973, Pickmere et al. 1973, McCandless et al. 1975, Waaland 1975) Differences in factors controlling reproduction have been reported for several red (West 1968, Edwards 1969, 1971) and brown seaweeds (Williams 1905, Liddle 1968), as well as in the seasonal variation of red algae (Zaneveld \& Barnes 1965). Little is known of the vertical distribution of isomorphic phases, except for studies by Norall et al. (1981) and Mathieson \& Burns (1975), which show that Ptilota serrata und Chondrus crispus sporophytes are more abundant in the low subtidal, and by Barilotti (1971), who reports on the greater abundance of Zonaria farlowii diploids at the upper limit of distribution of the species. Numerous cases of sporophytic dominance are known among red algae and these are often correlated with their geographic distribution (Dixon 1960, 1965, Edwards 1973, Whittick 1978). Nothing is known of biotic factors affecting the distribution of isomorphic phases.

Although little is known about differences between the reproductive phases of isomorphic species, it can be hypothesized that they arose as a result of different selective pressures. Differences between isomorphic phases might be less conspicuous than the ones described for heteromorphic species, but they may also represent adaptations to fluctuating environments. The magnitude of such differences should depend on the environment's stability. In the present study some ecological and ecophysiological aspects of the reproductive phases of 2 intertidal species of Iridaea are compared as a means of testing whether reproductive stages of isomorphic species have diverged ecologically, and whether such differences could be related to the degree of environmental fluctuations.

In the Northern hemisphere a tetrasporophytic dominance has been demonstrated for Iridaea cordata in central California (Hansen \& Doyle 1976), possibly by perennation of the crustose basal system (Hansen 1977). By contrast, in I. flaccida the gametophytic stage seems to be the most abundant (Abbott 1980). Although the taxonomy of South American species of Iridaea needs further clarification (Levring 1960), 3 species, namely I. laminarioides Bory, I. membranacea $J$. Agardh and I. ciliata Kützing, are presently recognized as major representatives of the genus in central Chile. A triphasic life cycle has recently been described for these species in culture (Candia 1983).

At our study site Iridea laminarioides and $I$. ciliata inhabit different intertidal levels. This vertical zonation thus provides a way of determining the effect on isomorphic species of two adjacent habitats (upper and lower intertidal) that differ in respect to environmental fluctuations imposed by tidal changes. We compare the external morphology, relative abundances and vertical and temporal distribution of female gametophytes and sporophytes of these two species in the field. In addition, we experimentally evaluate the effects of several abiotic factors on the growth rates of the two phases in each species, and measure the possible effect of common intertidal herbivores on their growth and abundance.

\section{MATERIAL AND METHODS}

Field studies. Field studies were carried out at Pelancura, $5 \mathrm{~km}$ north of San Antonio Port $\left(33^{\circ} 35^{\prime} \mathrm{S}\right.$; $\left.71^{\circ} 38^{\prime} \mathrm{W}\right)$, on a rocky platform bordering the north side of a channel approximately $15 \mathrm{~m}$ long. Part of the platform, ca. $10 \mathrm{~m}$ wide and $1 \mathrm{~m}$ high, is exposed during low tides, and has a zonation pattern characteristic of exposed localities in central Chile (see Santelices et al. 1981 for study-area description and authors of names for algae and invertebrates). Iridaea laminarioides is the most abundant species in the high and middle intertidal, while $I$. ciliata occurs mainly in the low intertidal. These species grow on rock as well as on Chthamalus spp. and Perumytilus purpuratus. Temporal and spatial changes in biomass were measured in samples taken monthly from August 3, 1982 to June 24, 1983, along 8 transects running perpendicular to the coast and extending from 1.1 to $1.8 \mathrm{~m}$ above zero tidal level (determined according to tidal height predictions by Anonymus 1983). The transects were approximately $1 \mathrm{~m}$ wide, $60 \mathrm{~cm}$ apart, and divided into three $86 \mathrm{~cm}$ long portions, roughly corresponding to 
high, middle and low tidal levels. All Iridaed blades enclosed in a randomly selected $20 \times 20 \mathrm{~cm}$ area at each tidal level were removed at the base with a spatula. The 24 samples which were collected each month at the 3 tidal levels were transported in plastic bags, and kept in a freezer until further measurements. To measure biomass changes, samples were washed in seawater, sorted by species and life history stage (female gametophytes, tetrasporophytes, and male and sterile plants together), blotted and weighed. Only wet weights were determined. To evaluate temporal variation of total biomass, means were obtained using al] samples in a given month. To measure vertical distribution of reproductive stages, samples from different tidal heights were treated independently. Biomass statistical parameters were estimated after log (biomass +1 ) transformations. Seasonal biomass values were compared by analysis of variance and by the Student-Newman-Keuls test.

In order to estimate monthly density and blade size, the above material was separated by tidal height. Thalli were measured from the base to the most distal end of the frond, grouped by size class ( 2 to 4,4 to 8 , 8 to 12,12 to 16 , and 16 to $20 \mathrm{~cm}$ length) and counted. Occasional subsample measurements were done for the sterile-male category. Density-biomass regression lines were compared by covariance analysis (Snedecor \& Cochran 1967). Values were grouped by season for size frequency analysis to increase sample size and thereafter subjected to the Kolmogorov-Smirnov 2 sample test (Conover 1980). Statistical tests were followed according to Sokal \& Rohlf (1969) unless stated otherwise.

In order to measure the proportion of plants that remain reproductive during winter, on April 25 and May 9, 1983, 24 cystocarpic and 22 tetrasporic Iridaea laminarioides plants were tagged by marking the substrate with Sikacement circles which surrounded the holdfasts of each individual. Small plastic labels were attached in the cement. In June, July and September of the same year, the number of individuals bearing fertile cystocarpic or tetrasporic fronds was recorded. Confidence intervals for cystocarpic and tetrasporic proportions were calculated after Steel \& Torrie (1980).

Laboratory studies. Abiotic factors: Fertile tetrasporic and cystocarpic fronds of Iridaea laminarioides and $I$. ciliata were collected at Pelancura prior to each experiment, thoroughly washed, sectioned, and left in 20 to $30 \mathrm{ml}$ of sterilized seawater until spores were liberated ( 1 to $2 \mathrm{~h}$ ). The spores in 10 to $40 \mathrm{ml}$ seawater were then transferred to Pyrex 3250 or to Petri dishes containing sterilized seawater, and incubated overnight at the experimental temperature and light intensity to allow spore settlement. Thereafter they were incubated in enriched seawater (after Chen et al. 1974) in culture chambers under controlled conditions of temperature $\left(10,15\right.$ or $\left.20^{\circ} \mathrm{C}\right)$, photon flux density, water movement and salinity.

The culture medium was changed every 5 to $7 \mathrm{~d}$ in all experiments. Occasionally, $\mathrm{GeO}_{2}\left(5 \mathrm{mg} \mathrm{l}^{-1}\right)$ was added to the medium to control diatom growth. The several irradiances $\left(10,35,60\right.$ and $\left.80 \mu \mathrm{E} \mathrm{m}^{-2} \mathrm{~s}^{-1}\right)$ used were provided by a variable number of cool white fluorescent light tubes $(40 \mathrm{~W})$; photon flux densities were measured with a LAMDA Quantum/Radiometer/ Photometer LI-COR 185A and a light: dark cycle of $12: \overline{12} \mathrm{~h}$ was used with all treatments. Different values of water movement were obtained by setting various rotary shakers (Lab Line) at different speeds $(0,50,100$ or $150 \mathrm{rpm})$. The different salinity values $(10,20,30,35$, $40,50 \%$ o) were obtained by diluting seawater with distilled water or adding $\mathrm{NaCl}$ to seawater; all values were controlled with a refractometer (American Optical Corp.). Experiments lasted ca. 40 d. Every 4 or 5 d, the diameter of 30 randomly chosen discs that developed from Iridaea spp. spores cultured under the several experimental conditions were measured in each of 2 replicate dishes using an inverted microscope. Comparisons of sporophytic and gametophytic growth are based on diameter measurements taken 4 to 5 wk after germination. The experimental data for temperature and light intensity were subjected to factorial analysis of variance (Sokal \& Rohlf 1969).

Herbivory studies: Experiments were carried out to compare the consumption of reproductive stages of adult fronds of Iridaea by 2 large-sized herbivores - the sea urchin Tetrapygus niger (Molina) and the snail Tegula atra - and of juveniles of both stages by 2 small herbivores - the limpets Siphonaria lessoni and Collisella ceciliana.

Tetrapygus niger of 2 sizes ( 3 to 3.5 and 5 to $6 \mathrm{~cm}$ test diameter) were collected from tide pools in Las Cruces $\left(33^{\circ} 29^{\prime} \mathrm{S} ; 71^{\circ} 38^{\prime} \mathrm{W}\right)$, a locality about $15 \mathrm{~km}$ north of Pelancura, taken immediately to the field station in Las Cruces, and placed in $50 \mathrm{l}$ tanks with circulating seawater $\left(0.6\right.$ turnover $\left.h^{-1}\right)$. Larger urchins (up to $6 \mathrm{~cm}$ test diameter) were placed in groups of 10 , while smaller ones were placed in groups of 12 individuals per tank. Whole cystocarpic and tetrasporic fronds of Iridaea laminarioides and $I$. ciliata, which had been recently collected at Pelancura, were blotted, weighed and placed in the tanks. Care was taken in providing a similar biomass ( 9 to $11 \mathrm{~g}$ ), and similar numbers of fronds per reproductive stage of each species $(7$ to 9 fronds per $I$. laminarioides stage and 4 to 5 fronds per $I$. ciliata stage) to the urchins. Experiments were done on June 10 and July 11, 1983. In the first experiment, 40 large and 36 small urchins were collected, deprived of food for $2 \mathrm{wk}$ and then placed in the experimental tanks. The second time, 30 large and 36 small sea 
urchins were collected, and placed under experimental conditions $24 \mathrm{~h}$ later.

Thirty-four individuals of Tegula atra 13.5 to $5 \mathrm{~cm}$ shell diameter) were collected at Las Cruces on May 14,1983 , placed in two 81 containers with circulating seawater, and deprived of food for $40 \mathrm{~d}$. Experiments were carried out as described for Tetrapygus niger, except that the same individuals were used for 3 experiments (Jun 24, Jul 12, Aug 9) and 3 to 5 fronds weighing 3 to $5.5 \mathrm{~g}$ per reproductive stage of each species were provided.

Fronds were left for 2 to $4 \mathrm{~d}$ in the tanks, blotted and weighed. Consumption was calculated as the difference in algal biomass between end and beginning of the experiment, and relative consumption as the proportion of each stage of each species consumed relative to the total consumption per container.

For experiments on consumption of Iridaea laminarioides juveniles, carpospores and tetraspores were cultured separately on $22 \times 22 \mathrm{~mm}$ cover slips for 2 mo at $15^{\circ} \mathrm{C}$ and $60 \pm 10 \mu \mathrm{E} \mathrm{m}^{-2} \mathrm{~s}^{-1}$. Cover slips were then transferred to 5 transparent plastic $1000 \mathrm{~cm}^{3}$ containers with holes drilled $4 \mathrm{~cm}$ above the bottom. Vaseline was used to stick 2 slips of each reproductive stage to the walls of each container. One container was kept as a control, and 10 Siphonaria lessoni or Collisella ceciliana individuals were placed in the remaining ones (2 replicates per invertebrate species) Containers were maintained with circulating seawater at $15^{\circ} \mathrm{C}$ and $12: \overline{12} \mathrm{~h}$ photoperiod for 6 to $10 \mathrm{~d}$. Sporeling abundance on cover slips was estimated as percent cover with a 100 point lattice of cover slip size. Cover was estimated as the mean of values measured in the four replicate slips containing each phase. Consumption was calculated as the cover difference between the end and the beginning of the experiment. Relative consumption was calculated as the consumption on one cover slip relative to the total consumption in that container. All relative consumption data were subjected to arcsine transformations. Sea urchin data were compared by a nested analysis of variance. Consumption of sporophytic and gametophytic juveniles was compared by Student's t-test for paired observations (all tests after Sokal \& Rohlf 1969).

\section{RESULTS}

\section{Field studies}

Spatial and temporal distribution patterns of the reproductive stages of both species of Iridaea at the 3 tidal levels studied are shown in Fig. 1 \& 2. I. laminarioides is the most abundant species at the high and middle tidal levels, whereas the low level is mainly

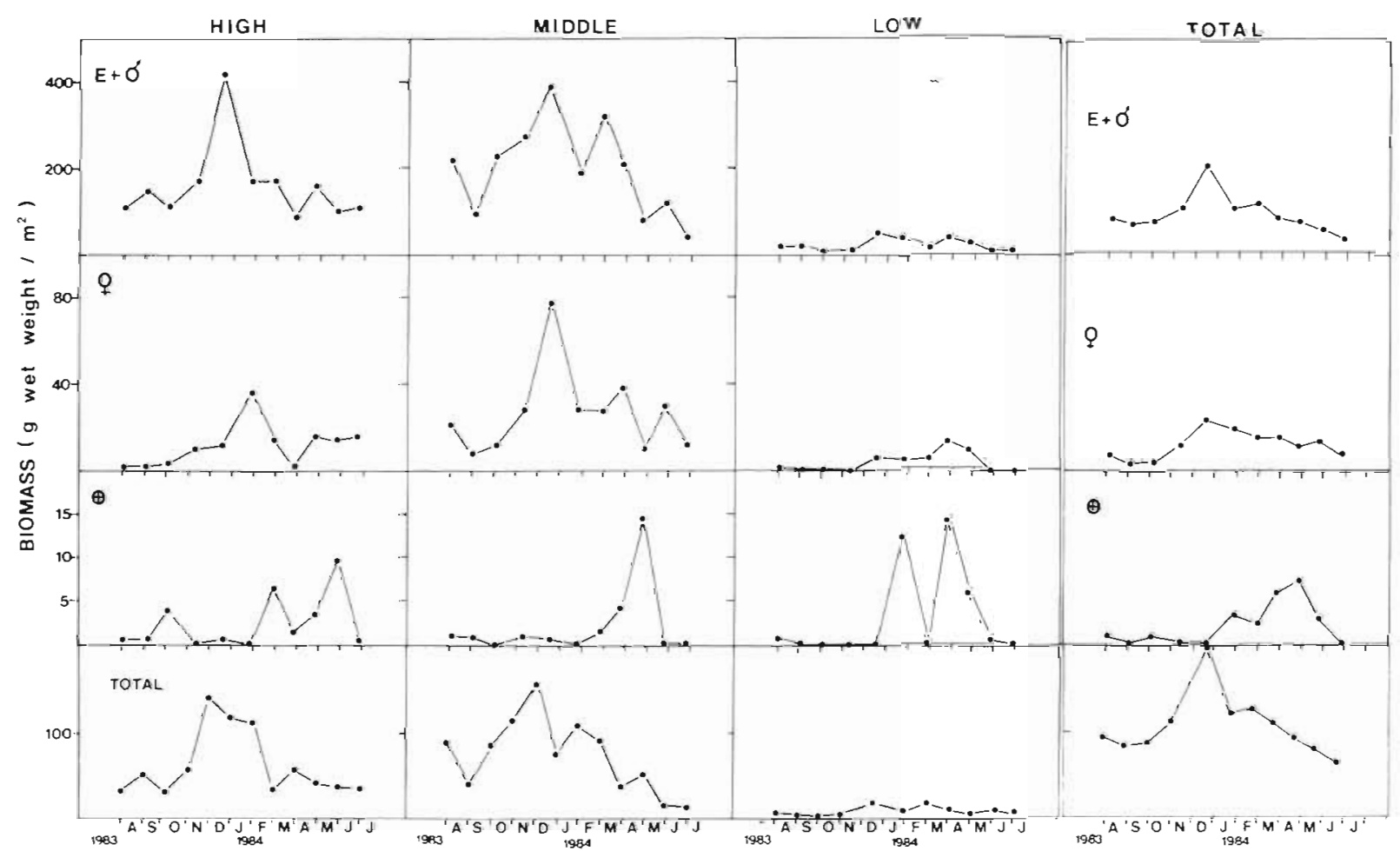

Fig. 1. Iridaea laminarioides. Seasonal biomass variation at 3 tidal heights (high, middle, low) and without tidal-height distinction (total). $\mathrm{E}+\delta$, sterile and male; $q$, cystocarpic; $\oplus$, tetrasporic. Points for each reproductive phase at each tidal height represent geometric means $(n=8)$. For seasonal variation of total biomass $n=24$ monthly samples, each of $400 \mathrm{~cm}^{2}$ 
occupied by I. ciliata. Monthly total biomass values show a marked seasonality for both species, with peaks in the summer. Average summer (Dec 28 to Mar 1st) and winter (Jun 24 to Aug 3) total biomass values differ significantly for $I$. laminarioides, while the winter biomass mean of $I$. ciliata differs significantly from the means of all other seasons.

Data on distributional patterns of reproductive stages of Iridaea laminarioides at the 3 tidal elevations indicate that the maximum abundance for each phase occurs at different seasons (Fig. 1). Sterile and male individuals of $I$. laminarioides showed a marked increase at the end of spring (Nov to Dec) at the high and the middle tidal levels, whereas almost no seasonal change was observed at the low level. Female gametophytes attained maximum biomass values in

Fig. 2. Iridaea ciliata. Seasonal biomass variation at 2 tidal heights (middle, low) and without tidal-height distinction (total). $E+\delta$, sterile and male; $q$, cystocarpic; $\oplus$, tetrasporic. Points for each reproductive phase at each tidal height represent geometric means $(\mathrm{n}=8)$. For seasonal variations of total biomass $n=24$ monthly samples, each of $400 \mathrm{~cm}^{2}$
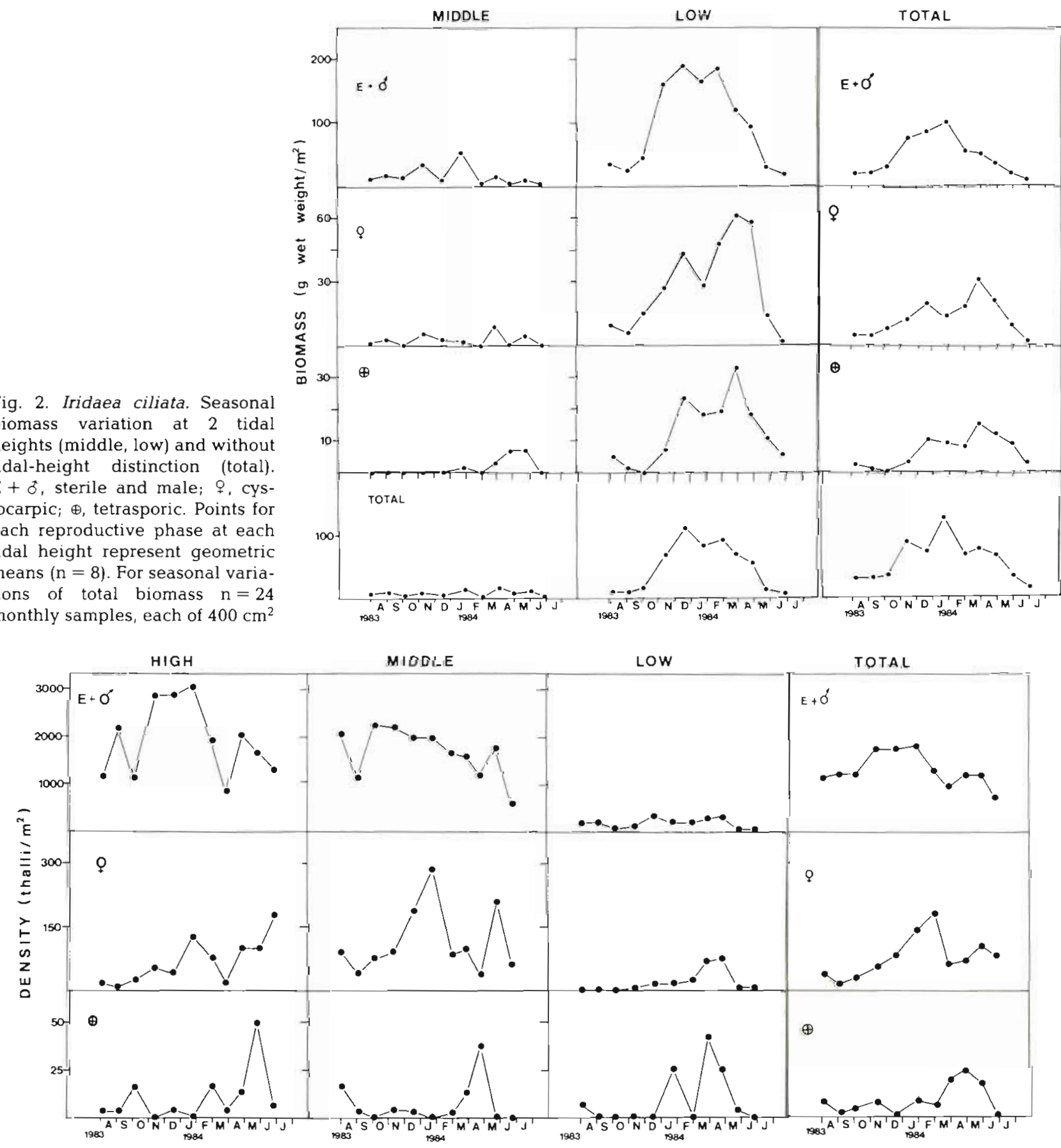

Fig. 3. Iridaea laminarioides. Seasonal density variation at 3 tidal heights (high, middle, low) and without tidal-height distinction (total). $\mathrm{E}+\delta$, sterile and male; $\mathcal{Q}$, cystocarpic; $\oplus$, tetrasporic 
December and January at the high and middle tidal levels, with only a small increment at the low level. Tetrasporophytes had a more marked seasonality than female gametophytes, variations being greatest at the middle and low tidal levels. The data on $I$. ciliata similarly show different time distributional patterns for the reproductive phases at the low tidal level (Fig. 2). Biomass variations are more gradual than for $I$. laminarioides, and occur mainly at the low tidal level. Both reproductive stages attain maximum biomass values during summer. Seasonal variation of the tetrasporic stage is slightly greater than for the cystocarpic stage.

In both species, sterile plants are most abundant during the whole year (Fig. $1 \& 2$ ), followed by female gametophytes. Tetrasporophytes were abundant only in late summer and early fall.

A succession of seasonal abundance is very evident for Iridaea laminarioides (Fig. 1) with tetrasporophytes having maximum abundance values later than female gametophytes. In $I$. ciliata a similar succession can be observed between sterile and reproductive phases (Fig. 2).

Density values (Fig. 3 \& 4) show a seasonal trend similar to that shown by biomass values. The density of tetrasporangial thalli of Iridaea laminarioides is markedly seasonal at the 3 tidal levels (Fig. 3), while the seasonal variation of cystocarpic thalli was greatest at the middle tidal level, and only a small increment occurred at the low level at the beginning of autumn. Variations in the density of $I$. ciliata cystocarpic thalli occurred mainly at the low tidal level (Fig. 4), whereas the density of tetrasporic thalli had a short autumn peak at the middle tidal level and more gradual varia- tions at the low tidal level. As for biomass values density data indicate a clear seasonal dephasing between the reproductive stages of I. laminarioides.

The proportions of cystocarpic and tetrasporic plants collected during the whole sampling period varies as a function of tidal height (Fig. 5). Each species exhibits a particular variation pattern of reproductive stages with tidal height. Density (Fig. 5a) and biomass (Fig. 5b) of Iridaea laminarioides tetrasporophytes increase markedly at the low level, whereas I. ciliata tetrasporophytes tend to decrease. When biomass percentages are examined relative to the total biomass (Fig. 5c) it can be seen that for both species the highest proportion of reproductive fronds occur at the low level.

Size class frequency distributions for both species also show seasonal differences for the various reproductive groups (Fig, $6 \&$ 7). The sterile-male category of both species is made up mainly of small thalli ( 2 to $4 \mathrm{~cm}$ long), suggesting that it contains mainly sterile plants. In this group only Iridaea ciliata thalli show a slight size increase in summer and autumn. Cystocarpic thalli of both species are significantly longer in summer than in winter (p <0.001), whereas only $I$. laminarioides tetrasporophytes are significantly longer in summer than in winter $(\mathrm{p}<0.05)$. A comparison of reproductive stages within seasons indicates that only in I. laminarioides can sporophytes reach a larger size than female gametophytes $(\mathrm{p}<0.05)$. No significant size differences were found during the rest of the year in either species. A comparison between reproductive stages based on the total frequencies shows no significant size differences for the sampling period as a whole.

Almost all the plants tagged in autumn survived

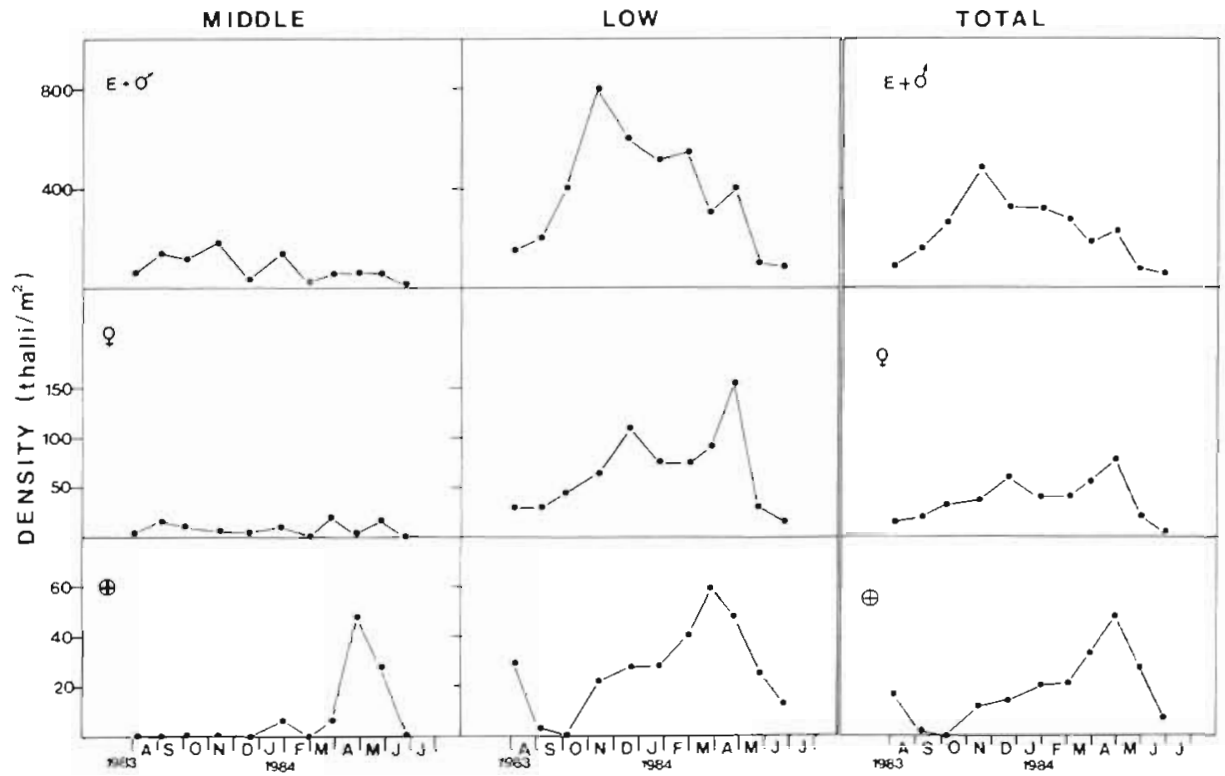

Fig. 4. Iridaea ciliata. Seasonal density variation at 2 tidal heights (middle, low) and without tidal-level distinction (total). $E+\delta$, sterile and male; $Q$, cystocarpic; $\oplus_{1}$ tetrasporic 
Fig. 5. Iridaea laminarioides \& I. ciliata. Proportion of female gametophytes (light bars) and tetrasporophytes (dark bars) as a function of tidal height, expressed as percentage of the total number of reproductive thalli (a), of the total reproductive biomass (b), and of the total biomass (c) for the whole sampling period
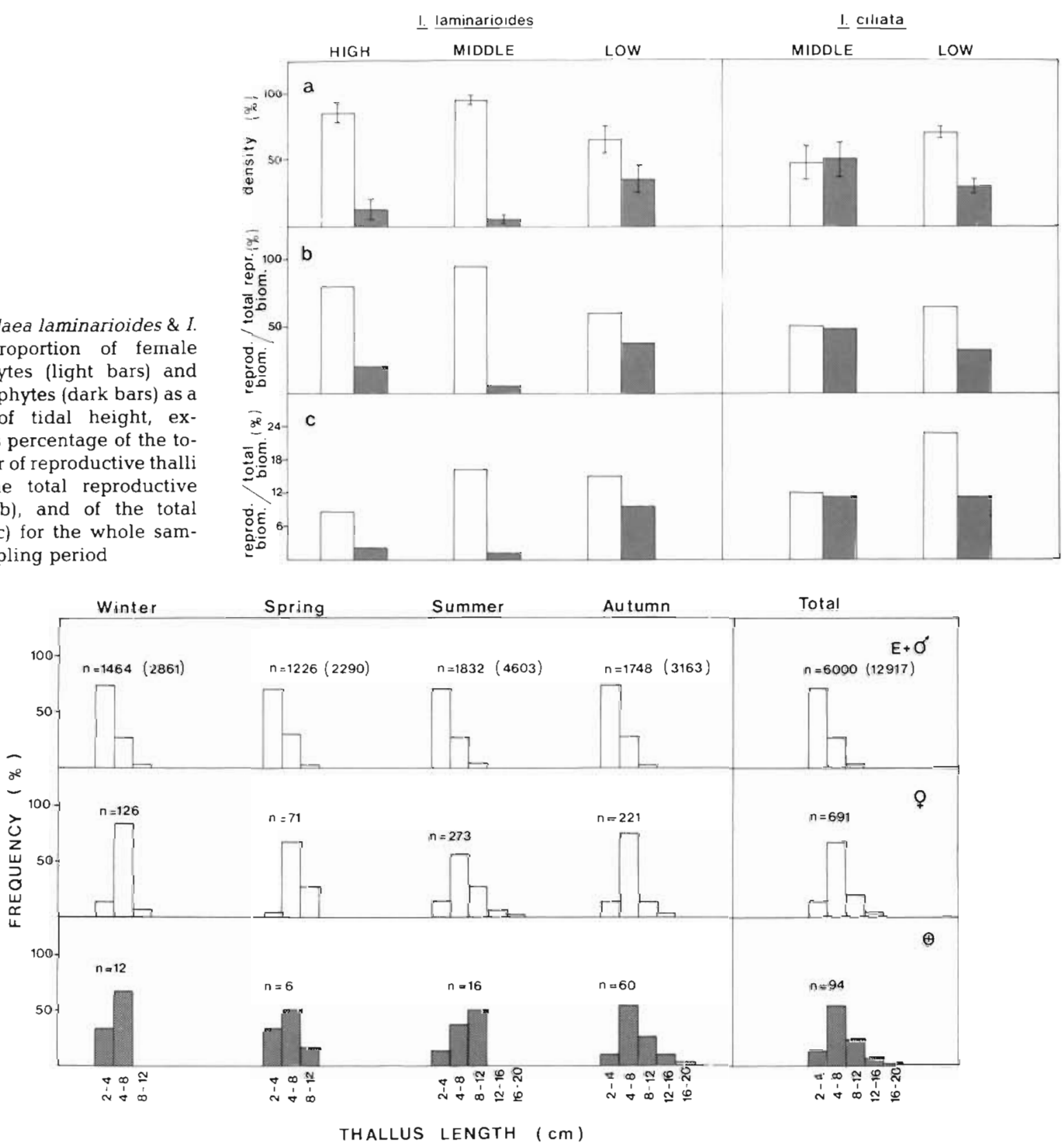

Fig. 6. Iridaea laminarioides. Seasonal size variation of sterile and male ( $E+\varnothing)$, cystocarpic $(q)$, and tetrasporic $(\oplus)$ thalli. Values in brackets: estimated sampling sizes when subsample measurement was taken

through the winter, either with only small sterile fronds arising from the holdfast, or with reproductive blades in addition to juveniles. Fig. 8 shows the decrease in the percentage of reproductive fronds from the time they were tagged until the beginning of spring. The small sample size (24 cystocarpic, 22 tetrasporic) probably accounts for the fact that no significant differences were found in the reproductive proportions of both phases.

In summary, the above field data suggest that there are significant differences between cystocarpic and tetrasporic plants in their seasonal abundance peaks and patterns of vertical distribution. These differences are more conspicuous in Iridaea laminarioides, where there is a clear predominance of cystocarpic thalli, a clear dephasing of maximum abundances and an increasing relative importance of the cystocarpic stage with tidal elevation. In I. ciliata the cystocarpic stage is less dominant, there is almost no dephasing of its reproductive stages, and the vertical relative abundance variation follows a pattern opposite to that of $I$. laminarioides. 
Fig. 7. Iridaed ciliata. Seasonal size variation of sterile and male $(E+\delta)$, cystocarpic ( $(9)$, and tetrasporic $(\oplus)$ thalli. Values in brackets: estimated sampling sizes when subsample measurement

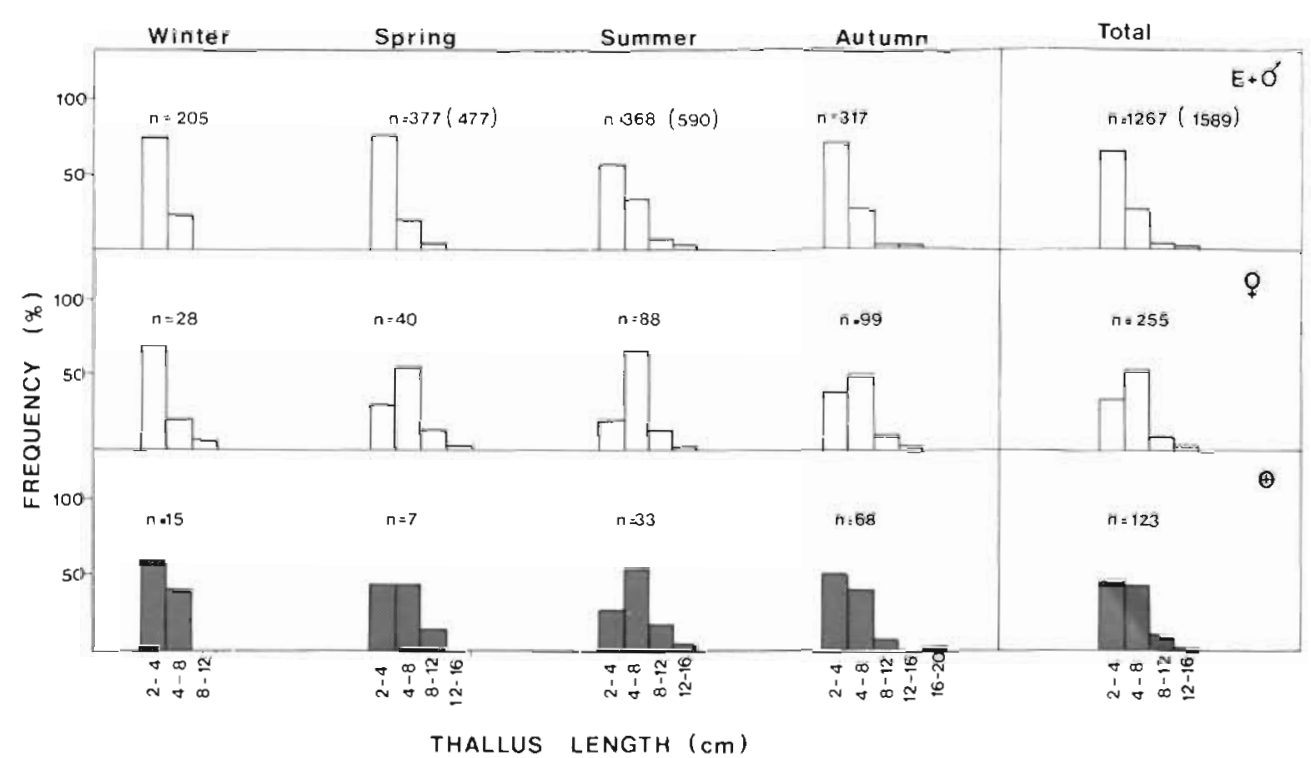

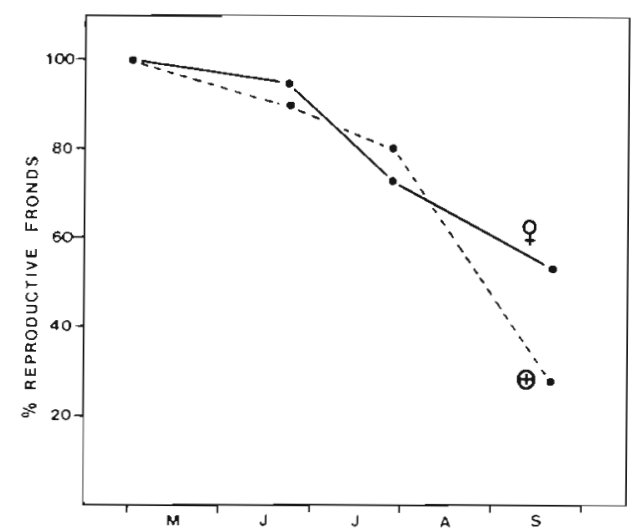

Fig. 8. Iridaed laminarioides. Variation of percentages of basal crusts that remained with reproductive fronds, following tagging of 24 cystocarpic and 22 tetrasporic crusts in autumn

\section{Laboratory studies}

\section{Culture experiments}

Sporelings of Iridaea Iaminarioides had maximum growth at $15^{\circ} \mathrm{C}$ and $60 \mu \mathrm{E} \mathrm{m} \mathrm{m}^{-2} \mathrm{~s}^{-1}$ (Fig. 9). At $10^{\circ} \mathrm{C}$ growth proceeded slowly and was not markedly affected by light flux. There was a significant effect of light flux on growth at higher temperatures. I. laminarioides sporophytes initially grew faster than gametophytes, but after 5 wk at $15^{\circ} \mathrm{C}$ and at 35 and $60 \mu \mathrm{E} \mathrm{m}^{-2} \mathrm{~s}^{-1}$, gametophytes were significantly larger than sporophytes. At $80 \mu \mathrm{E} \mathrm{m}^{-2} \mathrm{~s}^{-1}$ both reproductive stages had lower growth than at $60 \mu \mathrm{E} \mathrm{m}^{-2} \mathrm{~s}^{-1}$ (except for the sporophytes after 2 wk at $15^{\circ} \mathrm{C}$ ). Both $I$. laminarioides stages attain maximum sizes at $15^{\circ} \mathrm{C}$. Due to difficulties in controlling contamination at $20^{\circ} \mathrm{C}$, data taken at this temperature may not be completely reliable. Furthermore, at this temperature most disks acquired an irregular shape. These experiments show that after $5 \mathrm{wk}$, I. laminarioides gametophytes and sporophytes have reached significantly different sizes under the majority of the experimental conditions employed, and that under optimal experimental conditions the basal diameter of gametophytes surpasses that of sporophytes.

Iridaea ciliata growth under varying light fluxes and temperatures was also maximal at $15^{\circ} \mathrm{C}$ and at 35 and $60 \mu \mathrm{E} \mathrm{m}^{-2} \mathrm{~s}^{-1}$ (Fig. 9), but this species seems to have a smaller tolerance range to temperature, since almost no germination occurred at $20^{\circ} \mathrm{C}$, although they were incubated at this temperature on several occasions. As for I. laminarioides, the sporophytic stage surpassed the gametophytic stage in all experiments. The exception was at $15^{\circ} \mathrm{C}$ and at 35 and $60 \mu \mathrm{E} \mathrm{m}^{-2} \mathrm{~s}^{-1}$ where, after $4 \mathrm{wk}$, no significant difference in basal diameter was observed between the stages.

Although the response patterns of the phases are somewhat similar, a 3-way factorial analysis or variance shows that after 4 (Iridaea ciliata) or 5 ( $I$. laminarioides) weeks in culture there was a significant second order interaction ( $p<0.001$ ) of light intensity, temperature and reproductive stage for both species. Therefore, variations in gametophytic and sporophytic growth under different light and temperature regimes cannot be explained separately by each factor, but are the result of the interaction of temperature and light intensity with each reproductive stage.

Increasing water movement had a positive effect on sporeling growth in both species (Fig. 10). Stimulation of growth by water movement caused an early incidence on sporelings of Iridaea laminarioides, whereas 
Fig. 9. Iridaea laminarioides \& I. ciliata. Diameters of sporophytes $(\oplus)$ and gametophytes ( 9 o) grown at different combinations of temperature and light intensity. mean \pm 2 standard errors $(n=30)$

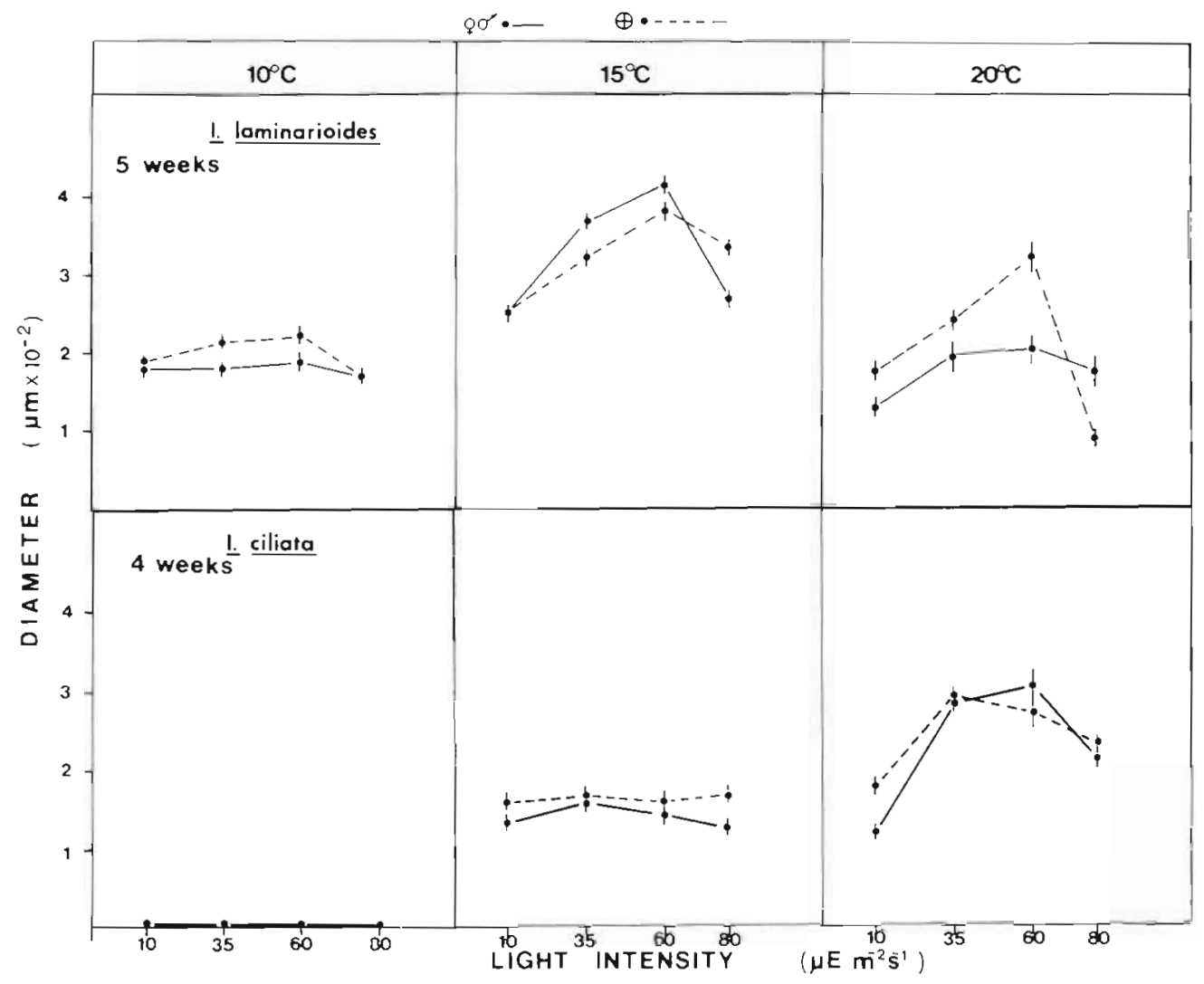

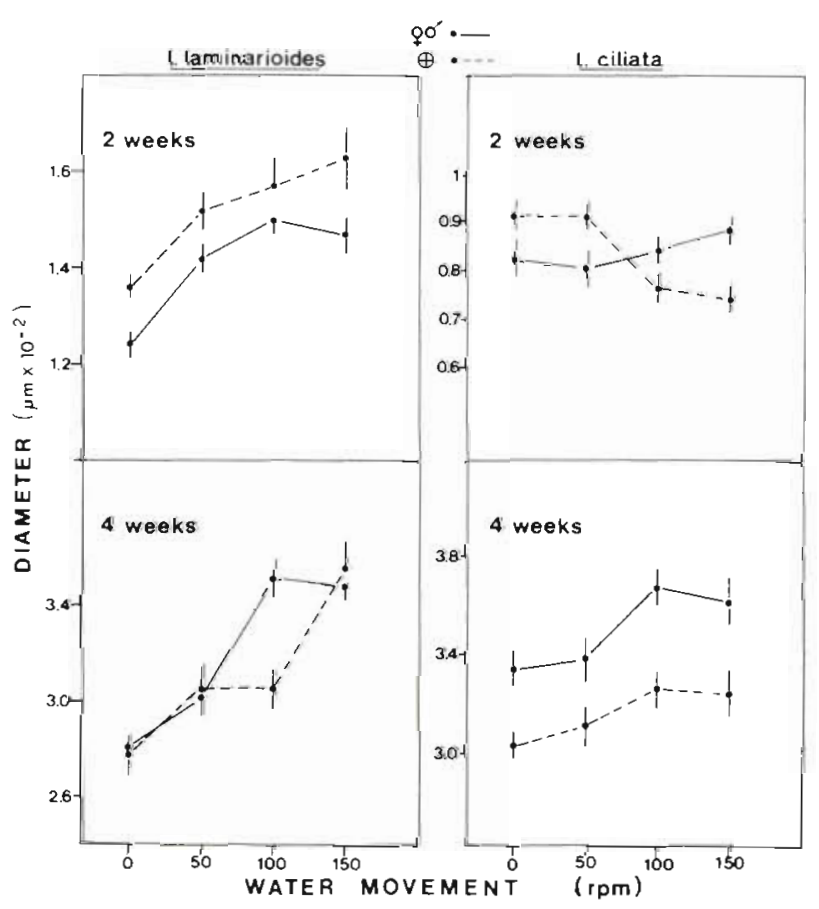

Fig. 10. Iridaea laminarioides \& $I$. ciliata. Diameters of sporophytes and gametophytes grown at $15^{\circ} \mathrm{C}, 60 \mu \mathrm{E} \mathrm{m} \mathrm{m}^{-2} \mathrm{~s}^{-1}$ and four intensities of water movements measured as revolutions per minute in rotary shakers. mean \pm 2 standard errors $(\mathrm{n}=30)$ only a small effect was shown by $I$. ciliata. Gametophy. tic and sporophytic sporelings of I. laminarioides show a similar response to variations in water movement except at $100 \mathrm{rpm}$, where for unknown reasons sporophytes grew much more slowly than gametophytes. The reproductive stages of $I$. ciliata had clearly different growth rates under all water movements tested (Fig. 10), although a similar trend in growth increment with increasing water movement was observed for both reproductive stages.

Growth rate of sporelings at different salinities (Fig. 11) was highest at concentrations lower than that of normal seawater. Both species grew very slowly at very low $(10 \%)$ and very high $(50 \%)$ salinities, but growth was similar at intermediate concentrations $(20,30,35$ and $40 \%$ ). Gametophytes and sporophytes basically had a similar response to salinity changes in the culture medium. However, growth rates of the reproductive stages of both species differed significantly for several of the concentrations tested.

\section{Herbivory experiments}

The relative consumption of adult cystocarpic and tetrasporic fronds of the 2 species of Iridaea by the sea urchin Tetrapygus niger and the snail Tegula atra are 


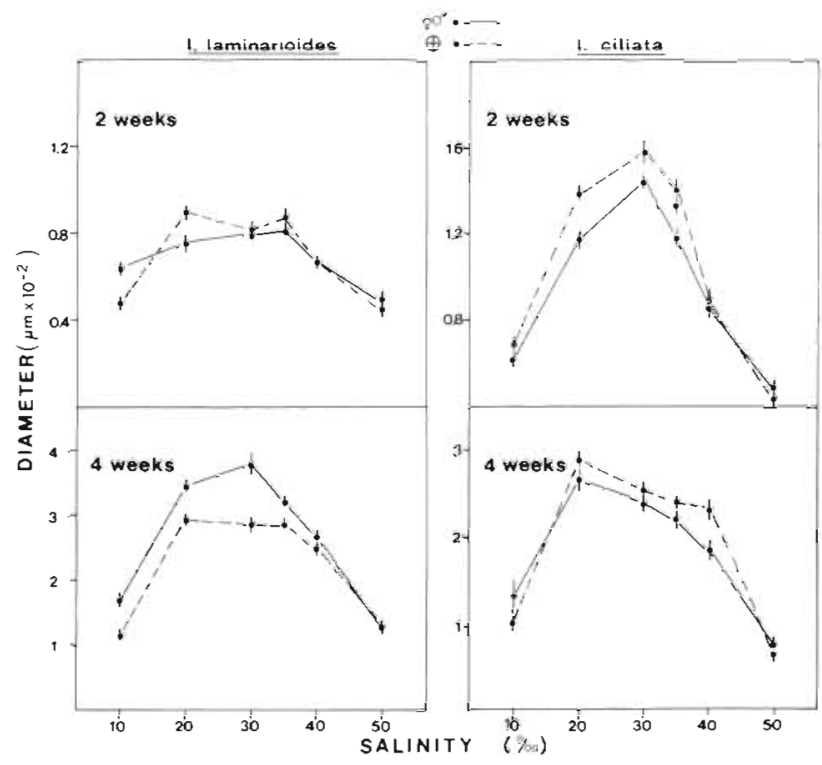

Fig. 11. Iridaea laminarioides \& I. ciliata. Diameters of sporophytes and gametophytes grown at $15^{\circ} \mathrm{C}, 60 \mu \mathrm{E} \mathrm{m} \mathrm{m}^{-2} \mathrm{~s}^{-1}$ and in 6 salinities. mean \pm 2 standard errors

shown in Fig. 12. No significant differences in consumption were obtained between the 2 size classes ( 3 to 3.5 and 5 to $6 \mathrm{~cm}$ test diameter) of $T$. niger (Fig. 12a). Consumption of I. laminarioides was significantly higher than that of $I$. ciliata $(\mathrm{p}<0.001)$, but no differences were obtained between the reproductive stages within each species. In the experiments with $T$. atra (Fig. 12b), no significant differences between reproductive stages or species were obtained.

Herbivory studies on juveniles of Iridaea laminarioides gave different results for the 2 limpets tested (Fig. 13). Relative consumption by Siphonaria lessoni did not differ significantly between the reproductive stages, but relative consumption by Collisella ceciliana was significantly higher for gametophytes than sporophytes $(p<0.05)$. Plant cover on slides maintained with no herbivores did not significantly change by the end of the experiment.

\section{DISCUSSION}

Even though the data obtained in this research are for a single study site - thus making it difficult to generalize about overall differences between the stages for the species examined - they point to differences in relative abundance, spatial and temporal pattern of distribution, effects of abiotic factors on growth and susceptibility to herbivory between cystocarpic and tetrasporic thalli of the 2 species of Iridaea.

The most important differences in abundance of the reproductive stages in any given species are the range

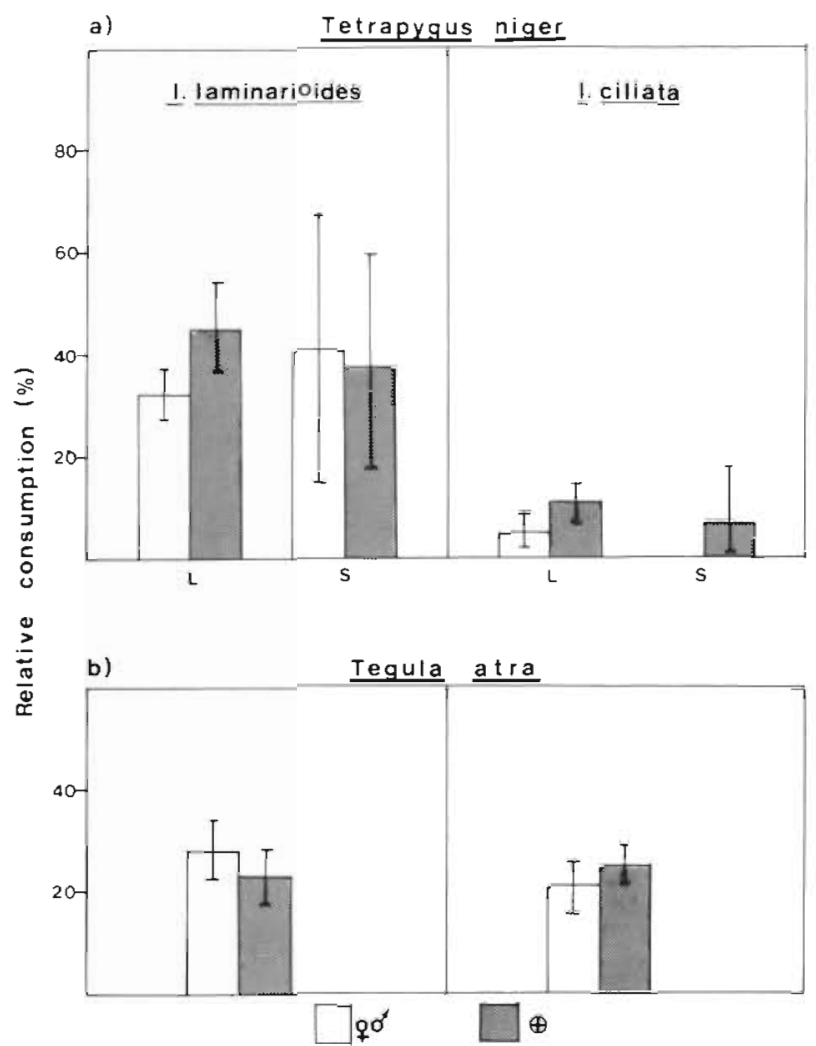

Fig. 12. Iridaea laminarioides \& I. ciliata. Relative biomass consumption of cystocarpic and tetrasporic fronds by (a) large $(\mathrm{L}, \mathrm{n}=7)$ and small $(\mathrm{S}, \mathrm{n}=6)$ sea urchins; (b) Tegula atra $(n=6)$. Bars: means \pm standard error

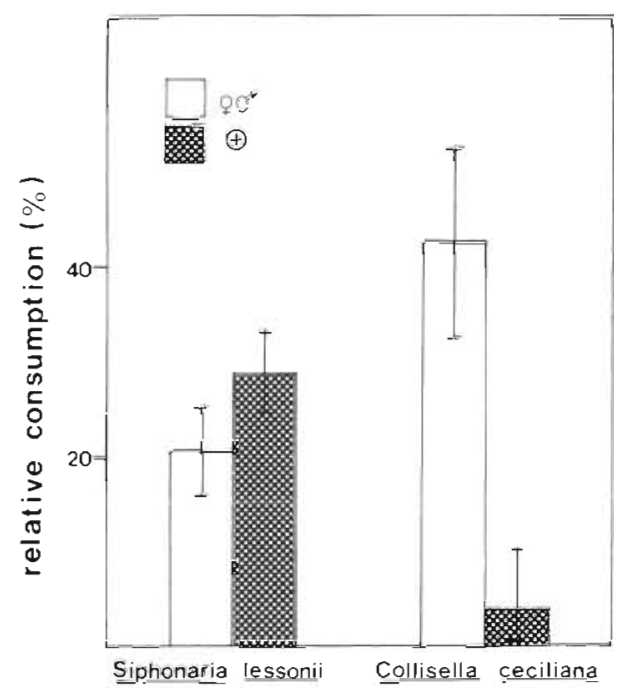

Fig. 13. Iridaea laminarioides. Relative consumption of gametophytes and sporophytes grown in the laboratory by 2 limpets $(n=4)$. Bars: means \pm standard error

of seasonal variation, the time of their maximum abundance and their relative temporal abundance. Female gametophytes of Iridaea laminarioides and I. ciliata have a less marked seasonal variation than 
sporophytes, mainly as a consequence of a substantial drop in density and size of tetrasporophytes in winter. A similar variation pattern of reproductive stages has been described for Chondrus crispus from New Hampshire (Mathieson \& Burns 1975) and Plymouth, Massachusetts (Prince \& Kingsbury 1973), where the presence of tetrasporophytes is drastically reduced during certain times of the year. Likewise, data obtained by Zaneveld \& Barnes (1965) from a floristic study in Chesapeake Bay, and results obtained by Abbott (1980) for Gigartina leptorhynchos in California, show that the tetrasporophytic stage undergoes greater fluctuations than the cystocarpic stage. All this suggests that the tetrasporic stage is more sensitive to seasonal changes than the cystocarpic stage.

A second important difference between reproductive stages is the time of maximum abundance. This difference is more pronounced between the reproductive stages of Iridaea laminarioides, which has a cystocarpic peak in summer and a tetrasporic peak in autumn. A similar displacement in abundance maxima has been reported by Mathieson \& Burns (1975) for 2 populations of Chondrus crispus from New Hampshire, and by Abbott (1980) for Gigartina leptorhynchos, $G$. canaliculata and Iridaea flaccida. In this last species the peak of tetrasporophyte abundance was later in the year than the peak for female gametophyte abundance. Thus, maturation of sporophytes and gametophytes seems to respond to different environmental factors, which may be a reflection of season.

A third important difference between reproductive phases is related to their relative abundance through time. Our data indicate predominance of cystocarpic thalli for both species at the study site. This inequality is greater in Iridaea laminarioides, where the cystocarpic biomass is between 80 and $100 \%$ of the total reproductive biomass during most of the year, than it is in $I$. ciliata. Cystocarpic fronds of $I$. ciliata usually constitute from 65 to $100 \%$ of the reproductive biomass, decreasing to $35 \%$ in fall. Among most Rhodophyta a sporophytic predominance is the rule, whereas in the Gigartinaceae there seems to be a tendency for the cystocarpic phase to be the most abundant. Such is the case for Rhodoglossum affine, Iridaea flaccida and Gigartina corymbifera from California (Abbott 1980), and Chondrus crispus from New Hampshire (Mathieson \& Burns 1975). The extreme case is represented by $G$. stellata from Nova Scotia, which has been reported to be exclusively female gametophytes with an apomictic life cycle (Chen et al. 1974). Exceptions to this pattern in the Gigartinaceae include C. crispus from Plymouth, whose reproductive stages are found in similar proportions (Prince \& Kingsbury 1973), and $I$. cordata from California, where tetrasporophytes are far more abun- dant than gametophytes (Hansen \& Doyle 1976). The dominance of the cystocarpic stage in several Gigartinaceae may imply that resistance to environmental fluctuations is not necessarily enhanced by a higher ploidy level. It may imply also that in the types of habitats where some of these populations of particular species were studied the environmental conditions favored gametophytes.

Dominance of the cystocarpic stage of Iridaea laminarioides decreases markedly at the low tidal level. In subtidal populations of Chondrus crispus (Mathieson \& Burns 1975) and Ptilota serrata (Norall et al. 1981), tetrasporophyte abundance also increases with depths. In constrast, cystocarpic thalli of $I$. ciliata occur only in the low intertidal zone. These opposite patterns in the vertical distribution of reproductive stages thus indicate that relative abundance of a particular stage may result from a set of factors whose effects vary from one species to another and from one study site to another.

The experiments show that for these 2 species of Iridaea sporelings, which belong to different phases respond in a similar manner to the environmental factors tested. No significant differences were found in the growth optima of gametophytes and tetrasporophytes of either species when temperature, light intensity, water movement or salinity were varied. However, the reproductive phases showed differences in growth rates, which were more pronounced for Iridaea laminarioides than for I. ciliata.

Results of the herbivory experiments indicate that susceptibility to grazing can vary with frond size and species of grazer. In the case of adult fronds, Tetrapygus niger and Tegula atra consumed equal amounts of cystocarpic and tetrasporic thalli, although T. niger preferred Iridaea laminarioides over $I$. ciliata fronds. Reproductive $I$. ciliata fronds are frequently thicker and larger than those of $I$. laminarioides, presumably slowing the buccal apparatus shearing rate of $T$. niger. On the other hand the chewing apparatus of $T$. atra allows it to rasp the frond surface, so that greater frond thickness or toughness seemingly do not impede ingestion.

The small grazer Siphonaria lessoni did not show any preference for reproductive-stage Iridaea laminarioides, but there was a significantly higher consumption of gametophytic rather than sporophytic specimens by Collisella ceciliana. Perhaps the sporophytes have some chemical or structural property that decreases their palatability for small herbivores.

The results of this study indicate that, although the tetrasporic and cystocarpic phases of Iridaea laminarioides and $I$. ciliata have a similar morphology, they do not exhibit identical responses to environmental variables. Some differences among the early 
developmental stages have been revealed experimentally. In the field, the reproductive stages differ in their relative abundances and in their patterns of spatial and temporal distribution. All these characteristics are most evident in I. laminarioides. For that reason, it could be concluded that this species has a greater degree of divergence between its stages in response to environmental variables.

The data obtained in this study tend to indicate that there exists a correlation between the degree of ecological divergence between phases in a given species and its vertical distribution. Iridaea laminarioides, with maximum divergence between stages, occupies an environment where it is periodically stressed, whereas $I$. ciliata, with smaller ecological divergence between phases, inhabits the low intertidal or protected subtidal, an environment subjected to less drastic fluctuations. Even though our data refer only to 2 species, it could be suggested that species continually exposed to stress may acquire a greater degree of dissimilarity between phases than those inhabiting more stable environments. The dominance of the cystocarpic stage of I. laminarioides high in the intertidal zone could be interpreted in terms of greater resistance to extreme conditions in comparison to the sporophytic stage, so that there maybe differential survival of the stages at some point in the life cycle. Growth experiments initiated from spores suggest that selection on the phases may occur at the sporeling level, as suggested by the higher gametophytic growth rate experience under the laboratory conditions tested. Dominance of the cystocarpic stage may also be the result of this stage being more persistent than the tetrasporic stage. Tagging of basal crusts has demonstrated that $I$. laminarioides is not strictly annual and that it can survive through the winter by keeping at least the basal system, in the same manner as previously described for $I$. cordata (Hansen 1977) and $I$. flaccida (Foster 1982). Due to the location of I. ciliata, no tagging was possible, but it is likely that the basal system is also persistent in this species. The maintenance of the basal system by perennation may represent a response to an environment where substrate is a limiting resource. Another plausible explanation for female gametophyte predominance is that they might be undergoing apomictic reproduction, which could be favoured by certain environmental factors.

It has been shown that intertidal algal zonation is determined both by physical and biotic factors. The upper limit appears to be set mostly by physical factors, whereas the lower limit appears to be dependent on biotic factors (Connell 1972). Interspecific competition frequently seems to be the main biotic factor (Schonbeck \& Norton 1978, Lubchenco 1980, Santelices et al. 1981, Foster 1982), herbivory mainly affects abundance but very rarely governs the presence of a species in a given habitat (Lubchenco 1980, Foster 1982). An analogous interpretation can be applied to the distribution of reproductive stages in an intertidal gradient. The preponderance of Iridaed laminarioides female gametophytes in the high intertidal may thus be determined by higher resistance to the stress imposed by this habitat, and the lower limit of both stages may be set by competition with $I$. ciliata. Female gametophytes of $I$. ciliata are only abundant at the low tidal level, suggesting that this stage has a smaller tolerance range to environmental fluctuations imposed by tidal cycles than the tetrasporic stage.

The fact that the cystocarpic stage of both species is more abundant than the tetrasporic stage suggests that the general validity of statements made by some authors (Stebbins \& Hill 1980, among others) with respect to the adaptability of diploidy over haploidy must be questioned. The results of the present study indicate that diploidy does not necessarily correlate with greater resistance to fluctuating environments.

Acknowledgements. This study is based on a thesis submitted by the first author as partial fulfillment of the requirements for a M. Sc. degree in Biological Sciences at the Universidad de Chile. Financial support from International Development Research Centre, Project 3-P-80-0107 to the second author and from Facultad de Ciencias Biológicas, Pontificia Universidad Católica de Chile is acknowledged with gratitude. The authors are grateful to I. A. Abbott, J. Armesto, K. Gill, M. Kalin-Arroyo, M. Littler, J. Ramus, R. Waaland and to 4 anonymous reviewers for suggestions and comments improving the manuscript.

\section{LITERATURE CITED}

Abott, I. A. (1980). Seasonal population biology of some carrageenophytes and agarophytes. In: Abbott, I. A., Foster, M. S., Eklund, L. F. (ed.) Pacific seaweed aquaculture. California sea grant college program, p. 45-53

Anonymous (1983). Tablas de Mareas de la costa de Chile. Instituto Hidrográfico de la Armada de Chile

Barilotti, D. C. (1971). Ecological implications of haploidy and diploidy for the isomorphic brown alga Zonaria farlowii Setch. et Gardn. J. Phycol. 7 (Suppl.): 4

Bold, H. C., Wynne, J. J. (1978). Introduction to the algae Prentice-Hall, New Jersey

Candia, A. (1983). Antecedentes reproductivos del género Iridaea Bory (Rhodophyta, Gigartinales) de Bahía Concepción, Chile. Memorias. Sociedad Latinoamericana de Acuicultura 5: 20

Conover, W. J. (1980). Practical non parametric statistics, 2nd ed. John Wiley \& Sons

Chen, L. C.-M., Edelstein, T., McLachlan, J. (1974). The life history of Gigartina stellata (Stackh.) Batt. (Rhodophyceae, Gigartinales) in culture. Phycologia 13: 287-294

Chen, L. C.-M., McLachlan, J., Neish, A. C., Schacklok, P. F. (1973). The ratio of kappa - to lambda - carrageenan in nuclear phases of the Rhodophycean algae Chondrus crispus and Gigartina stellata. J. mar. biol. Ass. U.K. 53: 11-16

Connell, J. H. (1972). Community interactions on marine rocky intertidal shores. A. Rev. Ecol. Syst. 3: 169-192 
Coon, D. A., Neushul, M., Charters, A. C. (1972). The settling behaviour of marine algal spores. Proceedings of the International Seaweed Symposium 7, Japan, p. 237-242

Dethier, M. N. (1981). Heteromorphic algal life histories: the seasonal pattern and response to herbivory of the brown crust, Ralfsia californica. Oecologia (Berl.) 49: 333-339

Dixon, P. S. (1960). Studies on marine algae of the British Isles: Ceramium shuttleworthianun (Kütz.) Silva, J. mar biol. Ass. U.K. 39: 375-390

Dixon, P. S. (1965). Perennation, vegetative propagation and algal life histories, with special reference to Asparagopsis and other Rhodophyta. Bot. Gothoburg. 3: 67-74

Edwards, P. (1969). Field and cultural studies on the seasonal periodicity of growth and reproduction of selected Texas benthic marine algae. Univ. Texas Contr. mar. Sci. 14: $59-114$

Edwards, P. (1971). Effects of light intensity, daylength and temperature on growth and reproduction of Callithamnion byssoides. Contr. Phycol. Sept. 1971: 163-174

Edwards, P. (1973). Life history studies of selected British Ceramium species. J. Phycol. 9: 181-184

Foster, M. S. (1982). Factor controlling the intertidal zonation of Iridaea flaccida (Rhodophyta). J. Phycol. 18: 285-294

Garbary, D., Grund, D. W., MacLachlan, J. (1980). Branching patterns and life history stages in Ceramium rubrum (Huds.) C. Ag. Nova Hedwigia 33: 249-260

Hansen, J. E. (1977). Ecology and natural history of Iridaea cordata (Gigartinales, Rhodophyta) growth. J. Phycol. 13: $395-402$

Hansen, J. E., Doyle, W. T. (1976). Ecology and natural history of Iridaed cordata (Rhodophyta, Gigartinaceae): population structure. J. Phycol. 12: 273-278

Istock, C. A. (1967). The evolution of complex life cycle phenomena: an ecological perspective. Evolution 21: 592-605

Levring, T. (1960). Contributions to the marine algal flora of Chile. Lunds Univ. Arsskr. N. F. Avd. 2, Bd 56: 1-85

Liddle, L. B. (1968). Reproduction in Zonaria farlowii. I. Gametogenesis, sporogenesis, and embriology. J. Phycol. 4: $298-305$

Littler, M. M., Littler, D. S. (1980). The evolution of thallus form and survival strategies in benthic marine macroalgae: field and laboratory tests of a functional form model. Am. Nat. 116: 25-44

Littler, M. M., Littler, D. S. (1983). Heteromorphic life strategies in the brown alga Scytosiphon lomentaria. J. Phycol. 19: 425-431

Lubchenco, J. (1980). Algal zonation in the New England rocky intertidal community: an experimental analysis. Ecology 61: 333-344

Lubchenco, J., Cubit, J. (1980). Heteromorphic life histories of certain marine algae as adaptations to variations in herbivory. Ecology 61: 676-687

Mathieson, A. C., Burns, R. L. (1975). Ecological studies of economic red algae. V. Growth and reproduction of natural and harvested populations of Chondrus crispus Stackhouse in New Hampshire. J. exp. mar. Biol. Ecol. 17: $137-156$
McCandless, E. L., Craigie, J. S., Hansen, J. E. (1975). Carrageenans of gametangial and tetrasporangial stages of Iridaea cordata (Gigartinaceae). Can. J. Bot. 53: 2315-2318

Mshigeni, K. E. (1976). Studies on the reproduction of selected species of Hypnea (Rhodophyta, Gigartinales) from Hawaii. Botanica mar. 19: 341-346

Nakamura, Y. (1954). The structure and reproduction of the genera Ceramium and Campylaephora in Japan with special reference to criteria of classification. Sci. Pap. Inst. Algol. Res. Fac. Sci, Hokkaido Univ. 4: 15-62

Nakamura, Y., Tatewaki, M. (1975). The life history of some species of the Scytosiphonales. Sci. Pap. Inst. Algol. Res. Fac. Sci., Hokkaido Univ. 6: 57-93

Norall, T. T., Mathieson, A. C., Kilar, J. A. (1981). Reproductive ecology of four subtidal red algae. J. exp. mar. Biol. Ecol. 54: 119-136

Pickmere, E. S., Parsons, M., Bailey, R. W. (1973). Composition of Gigartina carrageenan in relation to sporophyte and gametophyte stages of the life cycle. Phytochemistry 12: 2441-2444

Prince, J. S, Kingsburg, J. M. (1973). The ecology of Chondrus crispus at Playmouth, Massachusetts. П. Field studies. Am. J. Bot. 60: 964-975

Santelices, B. S., Montalva, S., Oliger, P. (1981). Competitive algal community organization in exposed intertidal habitats from Central Chile. Mar. Ecol. Prog. Ser. 6: 267-276

Schonbeck, M., Norton, T. A. (1978). Factors controlling the upper limits of fucoid algae on the shore. J. exp. mar. Biol. Ecol. 31: 303-313

Slocum, C. J. (1980). Differential susceptibility to grazers in two phases of an intertidal alga: advantages of heteromorphic generations. J. exp. mar. Biol. Ecol. 46: 99-110

Snedecor, G. W., Cochran, W. G. (1967). Statistical methods, 6th ed. Iowa State University Press, Iowa, USA

Sokal, R. R., Rohlf, F. J. (1969). Biometry. W. H. Freeman and Co., San Francisco

Stebbins, G. L., Hill, G. J. (1980). Did multicellular plants invade the land? A.m. Nat. 115: 342-353

Steel, R. G. D., Torrie, J. H. (1980). Principles and procedures of statistics, 2nd ed. Mc Graw Hill Book Co.

Waaland, J. R. (1975). Differences in carrageenan in gametophytes and tetrasporophytes of red algae. Phytochemistry $14: 1359-1362$

West, J. A. (1968). Morphology and reproduction of the red alga Acrochaetium pectinatum in culture. J. Phycol. 4: 89-99

Whittick, A. (1978). The life history and phenology of Callithamnion corymbosum (Rhodophyta: Ceramiaceae) in Newfoundland. Can. J. Bot. 56: 2497-2499

Williams, J. L. (1905). Studies in the Dictyoteaceae. III. The periodicity of the sexual cells in Dictyota dichotoma. Ann. Bot. 19: 531-559

Zaneveld, J. S., Barnes, W. D. (1965). Reproductive periodicities of some benthic algae in lower Chesapeake Bay. Chesapeake Sci. 6: 17-32 